chest after the operation and none needed ventilatory support.

Tushar J. Shah, MS, MCh

Department of Cardio-thoracic Surgery Rajasthan Hospital

Camp Road, Shahibaug

Ahmedabad-380004, India

12/8/74179

Reply to the Editor:

The reasons for respiratory embarrassment in flail chest injury are multiple, but the pain arising from movement of the spiky fractured ribs during the respiratory cycle plays a crucial role. Abolition of movement at the fracture sites is a key factor in minimizing the pain and improving pulmonary function. Different techniques including the use of various suture materials have been proposed to achieve internal fixation of the fractured ribs in flail chest injury. The aim of internal fixation is not just to achieve mere proximity of the two ends of a fractured rib. It is rather stabilization which is sought, and no amount of suturing with Vicryl sutures (Ethicon, Inc., Somerville, N.J.) can help to accomplish this objective. Bringing the two ends of a fractured rib together with Vicryl sutures would continue to allow movement at the fracture site during respiration, and this would negate the very purpose of internal fixation. The major reason for the pain would continue to be present, and the paradoxic movements of the flail segment would not be effectively curtailed because of the lack of provision of rigid support to the fractured ribs. Lack of stability would also ultimately hamper the effective clearance of bronchial secretions, by coughing, and lung expansion.

Another important point raised concerns the difficulty encountered in pinning the fracture sites in awkward locations. We do not advocate fixation of every single fractured rib. Pinning of even a few easily accessible sites is sufficient to allow normal respiratory physiology and can easily be accomplished through standard thoracotomy incisions.

Finally, regarding the question of splitting of ribs as a result of the use of the technique in question, it is understandable that use of any disproportionate force could make the matter worse. On the contrary, however, gentle and careful handling can obviate such mishaps. We have never encountered insurmountable difficulty with this technique. Once the entry of the Kirschner wire into the medullary cavity of a rib has been ensured, its further negotiation across the fracture site is fairly smooth and easy.

Zahoor Ahmed, FRCS

PO Box 28233

Abu-Dhabi, United Arab Emirates

12/8/74180

\section{A history of the valveless paraaortic counterpulsation device}

To the Editor

I read with interest the article entitled "A Valveless High Stroke Volume Counterpulsation Device Restores Hemodynamics in Patients With Congestive Heart Failure
Table I. History of paraaortic counterpulsation device as a left ventricular assist device

\begin{tabular}{|c|c|c|c|}
\hline $\begin{array}{c}\text { First } \\
\text { author }\end{array}$ & Year & Name of device & $\begin{array}{l}\text { Recipients } \\
\text { (duration) }\end{array}$ \\
\hline $\mathrm{Nose}^{2}$ & 1963 & Auxiliary left venticle & $\begin{array}{l}\text { Dogs (short- } \\
\text { term study) }\end{array}$ \\
\hline Gabby $^{3}$ & 1981 & $\begin{array}{l}\text { Extra-aortic balloon coun- } \\
\text { terpulsation }\end{array}$ & $\begin{array}{l}\text { Dogs (short- } \\
\text { term study) }\end{array}$ \\
\hline Nanas $^{4}$ & 1984 & $\begin{array}{l}\text { Aortic counterpulsation } \\
\text { device }\end{array}$ & $\begin{array}{l}\text { Sheep }(2-90 \\
\text { days) }\end{array}$ \\
\hline Utoh $^{5}$ & 1993 & $\begin{array}{l}\text { Extracorporeal pulsatile } \\
\text { assist device }\end{array}$ & $\begin{array}{l}\text { Calves (6-24 } \\
\text { days) }\end{array}$ \\
\hline Nanas $^{1}$ & 1996 & $\begin{array}{l}\text { Paraaortic counterpulsation } \\
\text { device }\end{array}$ & $\begin{array}{l}\text { Human beings } \\
\text { (1-54 days) }\end{array}$ \\
\hline
\end{tabular}

and Intractable Cardiogenic Shock Awaiting Heart Transplantation" by Nanas and associates ${ }^{1}$ in the January 1996 issue of the Journal. They reported clinical experiences with implantation of a valveless paraaortic counterpulsation device. Although all patients died while awaiting heart transplantation, I would like to congratulate Dr. Nanas and his colleague for showing promising circulatory assist performance of the device in their patients.

The concept of this type of device is not so new. This letter provides a brief historical review for better understanding of valveless paraaortic counterpulsation devices used as left ventricular assist devices (Table I). Since the first report by Nose, Schamaun, and Kantrowitz ${ }^{2}$ in 1963 , several studies of similarly designed devices have been presented in animal experiments. ${ }^{3-5}$ Gabby and Frater ${ }^{3}$ demonstrated the superiority of this type of device over intraaortic balloon pumping for providing circulatory assistance in a model of acute left ventricular failure. Utoh and colleagues ${ }^{5}$ demonstrated a $20 \%$ increase in the endocardial viability ratio and reported problems of systemic thromboembolism and bacterial infection in longterm calf experiments. Nanas and his colleagues began developing this type of device in $1984^{4}$ and finally applied for clinical use. ${ }^{1}$

Junichi Utoh, $M D, P h D$

First Department of Surgery Kumamoto University School of Medicine Kumamoto, Japan

\section{REFERENCES}

1. Nanas JN, Lolas CT, Charitos CE, Nanas SN, Margari ZJ, Agapitos EV, et al. A valveless high stroke volume counterpulsation device restores hemodynamics in patients with congestive heart failure and intractable cardiogenic shock awaiting heart transplantation. J Thorac Cardiovase Surg 1996;111: 55-61.

2. Nose Y, Schamaun M, Kantrowitz A. Experimental use of an electronically controlled prosthesis as an auxiliary left ventricle. Trans Am Soc Artif Intern Organs 1963;9:269-74.

3. Gabby S, Frater RW. The extra-aortic balloon counterpulsation as an assist device. Trans Am Soc Artif Intern Organs 1981;27:598-603.

4. Nanas JN, Olsen DB, Hamanaka Y, Chiang B-Y, Nielsen S, Hughes $S$, et al. Experience with a valveless, implantable 